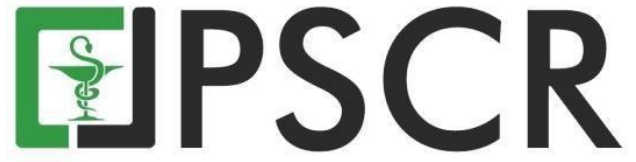

\title{
Potensi Biji Duwet (Syzygium cumini (L.) (Skeels.)) Sebagai Imunomodulator Pendamping Kemoterapi: Sebuah Ulasan
}

\author{
Ahmad Syauqy Tafrihani ${ }^{1,2}$, Christina Mutiara Putri Gono ${ }^{1,2}$, Nyssa Natasia $^{1,2}$ dan \\ Muthi Ikawati ${ }^{1,3 *}$ \\ ${ }^{1}$ Cancer Chemoprevention Research Center, Fakultas Farmasi, Universitas Gadjah Mada, Sekip Utara, \\ Yogyakarta 55281, Indonesia. \\ ${ }^{2}$ Program Studi Sarjana Farmasi, Fakulras Farmasi, Universitas Gadjah Mada, Sekip Utara, Yogyakarta 55281, \\ Indonesia. \\ ${ }^{3}$ Departemen Kimia Farmasi, Fakultas Farmasi, Universitas Gadjah Mada, Sekip Utara, Yogyakarta 55281, \\ Indonesia. \\ *email korespondensi: muthi_ikawati@ugm.ac.id \\ Received 05November2020, Accepted 29 June 2021, Published 15 July 2021
}

Abstrak: Mekanisme pertahanan sel kanker terhadap sistem imun tubuh merupakan ancaman bagi keberhasilan terapi kanker. Agen kemoterapi efektif dalam membantu proses eliminasi sel kanker, namun penggunaannya menginduksi imunosupresi. Ekstrak biji duwet (Syzygium cumini (L.) (Skeels.)) dan kandungan senyawanya dilaporkan memiliki berbagai aktivitas imunomodulator dan aktivitas antikanker. Namun, belum ada laporan yang mengulas potensi biji duwet sebagai agen imunomodulator pendamping kemoterapi kanker (ko-kemoterapi). Artikel ini disusun untuk mengulas potensi biji duwet sebagai imunomodulator pendamping kemoterapi. Berbagai literatur dari jurnal internasional dan sumber lain yang dipublikasikan mulai tahun 2005 ditelusuri dari database Pubmed, Scopus, GoogleScholar, dan lainnya. Berdasarkan studi literatur, ekstrak dan senyawa kandungan biji duwet, yaituasam galat dan mirisetin, dapat memodulasi sistem imun melalui berbagai jalur molekuler. Dapat disimpulkan bahwa biji duwet memiliki potensi untuk dikembangkan menjadi agen pendamping kemoterapi melalui aktivitas imunomodulatornya. Penelitian lebih lanjut pada model hewan uji kanker yang diberi ekstrak biji duwet dan kombinasinya dengan antikanker diperlukan untuk memvalidasi potensi tersebut.

Kata kunci: kanker; kemoterapi; duwet (Syzygium cumini); imunomodulator; kombinasi

Abstract. Potency of Duwet Seed (Syzygium cumini (L.) (Skeels.)) as an Immunomodulatory Co-Chemotherapeutic Agent: A Review. The defense mechanism of cancer cells against the body's immune system weakened the effectiveness of cancer therapy. Chemotherapy agents are effective in eradicating cancer cells, but their use induce immunosuppression as one of the side effects. The extract of "duwet" seed (Syzygium cumini (L.) (Skeels.)) and its compounds have been reported to show various immunomodulatory and anticancer activities. However, until now there is no report reviewing the potency of duwet seeds as an immunomodulator combination agent for chemotherapy (co-chemotherapy). This article reviewed the potency of "duwet" seeds as animmunomodulatory co-chemotherapy agent. Various literatures from international journals and other sources published in 2005 up to recent were retrieved from Pubmed, Scopus, Google scholar, and other databases. Based on literature studies, the extract and compound contents of "duwet" seeds, i.e. gallic acid and myricetin, modulate the immune system through various molecular pathways. It can be concluded that "duwet" seeds have a potency to be developed as a co-chemotherapy agent via its immunomodulatory activity. Further study using animal model treated with "duwet" seed extract and its combination with anticancer agent is needed to validate this potency. 
Keywords: cancer; chemotherapy; duwet (Syzygium cumini); immunomodulator; combination

1. Pendahuluan

WHO (2018) menyebutkan bahwa kanker merupakan penyebab kematian terbesar kedua secara global. Kementerian KesehatanRI (2019) mencatat angka kejadian penyakit kanker di Indonesia sebesar 136,2/100.000 penduduk berada pada urutan ke-8 di Asia Tenggara dan urutan ke-23 di Asia. Prevalensi kanker yang tinggi menunjukkan bahwa kanker adalah salah satu ancaman terbesar kelangsungan hidup manusia. Peneliti berupaya mengatasi hal ini termasuk dengan caramengembangkan agen antikanker baik dari bahan alam (Imanuel et al., 2021) maupun senyawa sintetik (Kesuma et al., 2018).Sel kanker mempunyai sistem pertahanan khusus untuk menghindari sistem imun tubuh yang dinamakan cancer immunosurveillance (Galluzzi et al., 2015). Dalam merespon sel kanker, tubuh melakukan respon imun tertentu untuk melawan sel kanker yang memiliki marker antigen tertentu. Sehingga dalam hal ini, imunitas tubuh merupakan hal yang penting dalam proses pertahanan untuk melawan sel kanker.

Penggunaan kemoterapi seperti doksorubisin dapat menyebabkan penurunan sistem imun sebagai efek samping dari penggunaannya (Hui-Chou et al., 2012), sehingga semakin memperburuk kondisi imun tubuh. Imunoterapi kanker merupakan salah satu alternatif terapi kanker yang menargetkan sistem imun sebagai perantaranya dan bekerja secara efektif khususnya ketika kanker telah memasuki fase resisten terhadap sistem imun. Pendekatan lain adalah penggunaannya agen imunostimulator sebagai pendamping kemoterapi untuk menangani efek samping imunosupresi dari agen kemoterapi.

Tanaman duwet (Syzygium cumini (L.) (Skeels.)) tersebar di berbagai daerah di Indonesia dengan nama yang beragam. Biji duwet seringkali menjadi sampah yang jarang dimanfaatkan, sehingga pengembangan penelitian pada biji duwet menjadi suatu hal yang menarik. Tanaman ini diketahui mengandung berbagai senyawa fenolik, flavonoid, dan terpenoid yang memiliki berbagai aktivitas antikanker (Arun et al., 2011) dan imunomodulator (Wang et al., 2020), sehingga berpotensi untuk dikembangkan sebagai agen imunoterapi kanker atau imunomodulator pendamping kemoterapi. Ulasan naratif ini diharapkan dapat menjadi rujukan untuk penelitian-penelitian selanjutnya, utamanya terkait dengan pengembangan potensi biji duwet sebagai imunoterapi kanker.

\section{Proses Cancer Immunosurveillance}

Sel kanker memiliki mekanisme khusus untuk menghindari proses eliminasi oleh sel imun. Proses ini melalui tiga tahap, yaitu eliminasi, equilibrium, dan escape (Galluzzi et al., 2015). Sel limfosit T sitotoksik (selanjutnya disebut sebagai sel Tc) memegang kendali proses 
eliminasi sel kanker. Menurut Wagner \& Koyasu (2019), proses eradikasi sel kanker dimulai dengan pengenalan antigen pada sel kanker yang berupa tumor-associated antigen dan major histocompatibility complex (MHC) kelas I yang berikatan dengan $T$ cell receptor (TCR) dan ko-reseptor cluster of differentiation 8 (CD8) pada sel Tc. Setelah proses pengenalan sel kanker terjadi, sel Tc mengeluarkan sekumpulan protein yang berfungsi melubangi sel kanker yang disebut dengan perforin. Selanjutnya, sel Tc akan mengeluarkan sitokin-sitokin yang akan menghancurkan sel kanker sehingga sel kanker mengalami apoptosis (Wagner \&Koyasu, 2019).

Sel kanker yang tidak teratasi pada fase eliminasi kemudian akan memasuki fase equilibrium dimana sel tersebut bermutasi dan menjadi lebih resisten terhadap serangan imun dengan mengekspresikan protein yang dapat menonaktifkan sel imun, salah satunya programmed-death ligand 1 (PD-L1) yang memiliki mekanisme yang sama dengan immune checkpoint pada MHC kelas I dengan sel Tc (Wagner \& Koyasu, 2019). Sel kanker yang resisten tersebut kemudian berkembang biak dengan tidak terkontrol dan menginduksi disfungsi imun yang dimediasi oleh faktor imunosupresif, antara lain interleukin-10 (IL-10) dan transforming growth factor (TGF)- $\beta$, sehingga semakin tidak terdeteksi oleh sel imun dan escape dari sistem imun tubuh (Galluzzi et al.., 2015).

\section{Kemoterapi dan Imunomodulator}

Intervensi penyembuhan dari luar tubuh merupakan satu-satunya harapan dalam menghadapi ganasnya sel kanker yang telah memasuki fase escape. Berbagai jenis terapi untuk mengatasi sel kanker telah ditemukan mulai dari operasi pengangkatan tumor, kemoterapi, radioterapi, sampai imunoterapi. Dalam perkembangannya, tiap-tiap terapi kanker memiliki efek sampingnya masing-masing.

Kemoterapi merupakan terapi yang umum digunakan dalam menekan progresivitas sel kankerdengan memanfaatkan suatu bahan kimia yang sangat kuat (Gibbs et al., 2016). Selain rute yang beragam, termasuk oral, topikal, dan parenteral (intravena, intraperitoneal, intra arteri, intra pleural intratrakeal, dan intratumoral), obat kemoterapi juga beragam. Beberapa obat kemoterapi yang sering digunakan antara lain adalah doksorubisin, 5-fluorourasil, 6merkaptopurin, metotreksat, taxanes, vinca alkaloid, dan cisplatin. Obat-obat tersebut bekerja sebagai alkylating agent dan menyebabkan kerusakan fungsi DNA, anti metabolik, menghambat pembentukan mikrotubulus, berperan sebagai antibiotik, menghambat topoisomerase, serta menghambat pembelahan sel (Bagnyukova et al., 2010).

Kemoterapi bekerja dengan menghambat pertumbuhan sel yang membelah dengan cepat, salah satu karakteristik dari sel kanker. Namun di sisi lain, kemoterapi dapat 
mempengaruhi sel-sel tubuh yang juga membelah dengan cepat, seperti folikel rambut, kuku, hematopoietic stem cells, dan sel epitel lambung. Karena itu, kemoterapi sering menimbulkan efek samping seperti mual, alopecia, turunnya nafsu makan, penurunan sel darah merah, dan imunosupresi (Hui-Chou et al., 2012; Zhang et al., 2005).Untuk mengurangi efek samping yang muncul, pemberian kemoterapi biasanya dikombinasikan dengan berbagai terapi lain seperti terapi adjuvan (misalnya terapi hormon dan imunoterapi) dan terapi neoadjuvan (misalnya operasi dan radiasi) yang tergantung pada jenis kanker dan tingkat keparahannya.

Imunomodulator merupakan salah satu jenis adjuvan kemoterapi. Imunomodulator bekerja dengan cara meningkatkan atau menurunkan respon imun tertentu. Adanya efek samping imunosupresi dari kemoterapi merupakan alasan penggunaan imunomodulator sebagai adjuvan kemoterapi (Galluzzi et al., 2015). Imunomodulator dapat meningkatkan respon imun melalui mekanisme aktivasi sitokin anti-kanker seperti IFN- $\gamma$, IL-6, dan sebagainya. Imunomodulator juga dapat bekerja sebagai inhibitor protein pro-kanker seperti TGF- $\beta$, nuclear factor (NF)-кB, IL-2, dan lain-lain (Travis \& Sheppard, 2014). Selain itu, imunomodulator juga dapat digunakan untuk mengaktivasi sel-sel imun melalui mekanisme aktivasi toll-like receptor (TLR) (Chen \& Yu, 2016).

\section{Morfologi dan Penggunaan EmpirisTanaman Duwet}

Tanaman duwet atau jamblang (Syzygium cumini (L.) (Skeels.)) merupakan salah satu tumbuhan tropis yang dapat tumbuh hingga ketinggian $30 \mathrm{~m}$. Tanaman ini memiliki daun yang tebal dengan panjang sekitar 6-12 $\mathrm{cm}$, lebar 5-9 $\mathrm{cm}$, berwarna hijau, dengan helaian daun yang berbentuk lonjong, pertulangan menyirip, dan permukaan atas daun yang halus dan mengkilap (Pai et al., 2013). Buah dari tanaman ini berbentuk lonjong dengan panjang 2-3 $\mathrm{cm}$, saat masih muda buah duwet berwarna hijau, setelah masak warnanya akan berubah menjadi ungu kehitaman dengan daging buah berwarna ungu. Setiap buah memiliki satu biji yang berbentuk lonjong dengan panjang 1-2 cm, keras, dan berwarna putih keunguan (Ramya et al., 2012).

United States Department of Agriculture (2015) mengklasifikasikan tanaman duwet dalam divisi Magnoliophyta, kelas Magnoliopsida, orde Myrtales, famili Myrtaceae, genus Syzygium, dan spesies Syzygium cumini (L.) Skeels. Duwet merupakan tumbuhan asli yang berasal dari Indonesia, India, Sri Lanka, beberapa daerah di Cina, Cambodia, Laos, dan Malaysia (POWO, 2019). Tumbuhan ini juga telah diperkenalkan dan dinaturalisasi di beberapa negara seperti Florida, Hawaii, Venezuela, dan Filipina (POWO, 2019). Di India, tanaman duwet banyak digunakan dalam pengobatan ayurveda untuk pengobatan diabetes 
mellitus, selain itu digunakan juga dalam pengobatan tradisional sebagai obat untuk keluhan pencernaan, disentri, wasir, dan kanker (Ayyanar\& Subash-Babu, 2012).

\section{Profil Fitokimia dan Metode Ekstraksi Biji Duwet}

Kandungan fitokimia biji duwet telah banyak dilaporkan (Tabel 1). Kandungan terbesar senyawa pada biji duwet adalah asam galat dengan kadar sebesar 531,8 mg/g sampel (Syama et al., 2017). Asam galat identik dengan buah duwet yang berasa masam dan kelat. Adanya kandungan asam galat yang banyak pada buah duwet ini menyebabkan tingginya kandungan asam galat pada biji duwet pula (Ramya et al., 2012). Selain asam galat, asam elagat juga memiliki kadar yang cukup tinggi dalam biji duwet. Biji duwet juga kaya akan flavonoid seperti mirisetin, kuersetin serta terpenoid seperti bisiklogermakren dan $\alpha$-pinen yang mana senyawa-senyawa ini yang berperan dalam berbagai aktivitas biji duwet (Banerjee \& Narendhirakannan, 2011; Gowri \& Vasantha, 2010; Syama et al., 2017). Di samping metode ekstraksi perkolasi dan Soxhletasi dengan pelarut organik, distilasi juga dilakukan untuk mengambil minyak atsirinya.

\section{Aktivitas Farmakologi Ekstrak Biji Duwet}

Kandungan kimia pada biji duwet ini terkorelasi dengan berbagai aktivitas biologinya (Tabel 2). Aktivitas farmakologi tanaman duwet, secara spesifik ekstrak dari bagian bijinya, khususnya aktivitas antikanker dan imunomodulasi. Esktrak-ekstrak yang diantaranya mengandung alkaloid dan flavonoid atau minyak atsiri dengan kandungan utama monoterpen tersebut menunjukkan aktivitas anti-oksidan (Banerjee \& Narendhirakannan, 2011), sitotoksik dan antiproliferatif (Banerjee \& Narendhirakannan, 2011; Ruthurusamy et al., 2015), serta meningkatkan jumlah limfosit dan mengaktivasi makrofag (Mastan et al., 2008; Rodrigues et al., 2015).

\section{Aktivitas Imunomodulator Senyawa Kandungan Biji Duwet}

Biji duwet mengandung senyawa-senyawa (Tabel 1) yang telah terbukti memiliki berbagai aktivitas imunomodulator melalui berbagai mekanisme sebagaimana dirangkum pada Tabel 3. Menariknya, senyawa-senyawa pada biji duwet, contohnya kuersetin, tidak hanya memiliki aktivitas imunomodulator, akan tetapi juga sekaligus memiliki aktivitas antikanker dan antioksidan (Li et al., 2014; Wang et al., 2020).

Asam galat terbukti dapat meningkatkan proliferasi limfosit pada mencit yang diinduksi cisplatin sebagaimana tertera pada Tabel 3. Asam galat menginduksi ekspresi IFN- $\gamma$ yang merupakan salah satu sitokin yang berperan penting dalam modulasi sistem imun. Biji duwet dibandingan dengan tanaman lain memiliki kandungan asam galat yang tinggi ( $72 \mathrm{mg} / \mathrm{g}$ biji) (Balyan \& Sarkar, 2017) dibandingkan anggur 35-65 mg/g, nangka (27,7 mg/g), serta leci 
17,9 mg/g biji (Balyan \& Sarkar, 2017). Kandungan asam galat yang tinggi inilah yang menyebabkan aktivitas dominan dari biji duwet. Menurut penelitian yang dilakukan oleh Yadav et al. (2012), aktivitas farmakologi asam galat sebagai imunomodulator dapat ditingkatkan dengan cara penambahan farmakofor sebagai agen imunomodulator dengan mekanisme inhibisi residu IFN- $\alpha$, IL-4, dan IL-6 (protein imunosupresif). Shruthi et al. (2018) menyatakan bahwa asam galat dapat menginduksi sistem imun sel normal yang mengalami efek samping obat cisplatin. Hal ini menunjukkan potensi dari biji duwet dengan kandungan tingginya sebagai imunomodulator. Asam galat sendiri akan mengalami absorpsi dalam saluran pencernaan dan mengalami metabolisme menjadi asam 4-O-metilgalat (Yang et al., 2020). Lebih lanjut, konsumsi dari asam galat sendiri dapat meningkatkan respon imun mukosa pada pencernaan sehingga baik untuk pengidap kanker pencernaan seperti kanker kolorektal (Yang et al., 2020).

Tabel 1. Kuantifikasi kandungan senyawa biji duwet (Syzygium cumini (L.) (Skeels.)) menggunakan metode HPLC (high performance liquid chromatography) dan GCMS (gas chromatography-mass spectroscopy).

\begin{tabular}{|c|c|c|c|c|c|}
\hline Senyawa & Struktur & $\begin{array}{c}\text { Pelarut } \\
\text { ekstraksi }\end{array}$ & $\begin{array}{c}\text { Kandungan (mg/g } \\
\text { sampel kering) }\end{array}$ & $\begin{array}{l}\text { Metode } \\
\text { analisis }\end{array}$ & Referensi \\
\hline $\begin{array}{l}\text { Asam } \\
\text { galat }\end{array}$ & & Etil asetat & 531,80 & HPLC & Syama et al., 2017 \\
\hline $\begin{array}{l}\text { Asam } \\
\text { elagat }\end{array}$ & & $\begin{array}{l}\text { Metanol } \\
70 \%\end{array}$ & 222,18 & HPLC & Syama et al., 2017 \\
\hline $\begin{array}{l}\text { Asam } \\
\text { ferulat }\end{array}$ & & Etil asetat & 21,37 & HPLC & Syama et al., 2017 \\
\hline $\begin{array}{c}\text { Asam } \\
\text { klorogenat }\end{array}$ & & $\begin{array}{l}\text { Metanol } \\
70 \%\end{array}$ & 42,46 & HPLC & Syama et al., 2017 \\
\hline Mirisetin & & Metanol & 100,53 & HPLC & Syama et al., 2017 \\
\hline Kuersetin & & Etil Asetat & 114,49 & HPLC & Syama et al., 2017 \\
\hline $\begin{array}{l}\text { Bisikloger- } \\
\text { makren }\end{array}$ & & Etanol & $\begin{array}{c}\text { tidak } \\
\text { dikuantifikasi }\end{array}$ & GC-MS & $\begin{array}{l}\text { Banerjee \& } \\
\text { Jarendhirakannan, } 2011\end{array}$ \\
\hline
\end{tabular}


Tabel 2. Penelitian tentang aktivitas berbagai jenis ekstrak biji duwet (Syzygium cumini (L.) (Skeels.)).

\begin{tabular}{|c|c|c|c|c|c|}
\hline $\begin{array}{l}\text { Jenis } \\
\text { ekstrak }\end{array}$ & $\begin{array}{l}\text { Metode } \\
\text { ekstraksi }\end{array}$ & $\begin{array}{l}\text { Golongan } \\
\text { senyawa }\end{array}$ & $\begin{array}{c}\text { Desain } \\
\text { uji }\end{array}$ & Aktivitas & Referensi \\
\hline $\begin{array}{l}\text { Ekstrak } \\
\text { metanol }\end{array}$ & Perkolasi & $\begin{array}{l}\text { Alkaloid, asam } \\
\text { amino, flavonoid, } \\
\text { glikosida, } \\
\text { fitosterol, saponin, } \\
\text { steroid, tanin, } \\
\text { triterpen }\end{array}$ & in vivo & $\begin{array}{l}\text { Meningkatkan } \\
\text { jumlah sel darah } \\
\text { putih dan limfosit }\end{array}$ & $\begin{array}{l}\text { Mastan et } \\
\text { al., } 2008\end{array}$ \\
\hline \multirow{2}{*}{$\begin{array}{c}\text { Ekstrak } \\
\text { etanol }\end{array}$} & \multirow{2}{*}{ Soxhletasi } & \multirow{2}{*}{$\begin{array}{l}\text { Polifenol, } \\
\text { seskuiterpen, } n \text { - } \\
\text { alkana }\end{array}$} & in vitro & $\begin{array}{l}\text { Anti-radical } \\
\text { scavenging }\end{array}$ & \multirow{2}{*}{$\begin{array}{l}\text { Banerjee \& } \\
\text { Narendhira } \\
\text { kannan, } \\
2011\end{array}$} \\
\hline & & & in vitro & $\begin{array}{l}\text { Sitotoksik pada sel } \\
\text { kanker leher Rahim } \\
\text { HeLa }\end{array}$ & \\
\hline $\begin{array}{l}\text { Ekstrak } \\
\text { etil } \\
\text { asetat }\end{array}$ & Soxhletasi & $\begin{array}{l}\text { Alkaloid, steroid, } \\
\text { flavonoid, saponin, } \\
\text { kuinon, tanin, } \\
\text { protein }\end{array}$ & in vitro & $\begin{array}{l}\text { Menghambat } \\
\text { proliferasi sel kanker } \\
\text { payudara MCF-7 }\end{array}$ & $\begin{array}{l}\text { Ruthurusa } \\
\text { my et al., } \\
2015\end{array}$ \\
\hline $\begin{array}{l}\text { Minyak } \\
\text { atsiri }\end{array}$ & Distilasi & $\begin{array}{l}\text { Monoterpen }(\alpha- \\
\text { pinene, }(Z)-\beta \text { - } \\
\text { ocimene, }(E)-\beta \text { - } \\
\text { ocimene })\end{array}$ & in vitro & Aktivasi makrofag & $\begin{array}{l}\text { Rodrigues } \\
\text { et al., } 2015\end{array}$ \\
\hline
\end{tabular}

8. Potensi Pengembangan Biji Duwet sebagai AgenImunomodulator Pendamping Kemoterapi dan Imunoterapi

Imunoterapi kanker merupakan salah satu tren pengembangan terapi kanker akhir-akhir ini. Berbagai strategi imunoterapi dilakukan mulai dari tingkat molekuler sampai terapi adoptif sel T (Liu \&Guo, 2018). Jalur molekuler dari imunoterapi yang mungkin dilakukan antara lain melalui jalur TLR/Myd88 (Lee et al., 2020), inhibitor reseptor molekul yang mempengaruhi sel $\mathrm{T}_{\text {reg }}$ seperti TGF- $\beta$ (Liu \&Guo, 2018), injeksi sitokin imunomodulator seperti IL-2, IFN- $\gamma$ (Liu \&Guo, 2018), atau regulasi reseptor sitokin imunomodulator (Yadav et al., 2012).

Aktivitas imunomodulator dari ekstrak dan senyawa pada biji duwetyang menjadi dasar bahwa biji duwet memiliki potensi yang besar untuk diadopsi menjadi agen imunoterapi untuk kanker (Tabel 1 dan 3). Penelitian Yadav et al. (2012) menunjukkan bahwa asam galat dapat diderivatisasi dengan penambahan gugus naftofenon sebagai farmakofor residu sisi aktif IL-4, IL-6, dan IFN- $\alpha 2$ yang merupakan mediasi imunomodulator. Kandungan asam galat yang tinggi pada biji duwet (Tabel 2) menunjukkan salah satu potensi besar yang 
menunjukkan bahwa biji duwet dapat diarahkan menjadi agen imunoterapi kanker melalui jalur penelitian yang telah disebutkan oleh Yadav et al. (2012). Selain asam galat, mirisetin pada biji duwetdapat menginhibisi reseptor TGF- $\beta$ dengan afinitas yang lebih tinggi dibandingkan dengan kontrol ligan inhibitor TGF- $\beta$ (Singhet al., 2017).

Tabel 3. Aktivitas imunomodulator senyawa yang terkandung dalam biji duwet (Syzygium cumini (L.) (Skeels.)). IFN- $\gamma$ : interferon- $\gamma$; ROS: reactive oxygen species; TGF- $\beta$ : transforming growth factor- $\beta$; IL-8: interleukin-8.

\begin{tabular}{|c|c|c|c|c|}
\hline Senyawa & Aktivitas & $\begin{array}{c}\text { Desain } \\
\text { uji }\end{array}$ & Mekanisme Molekuler & Referensi \\
\hline $\begin{array}{l}\text { Asam } \\
\text { galat }\end{array}$ & $\begin{array}{l}\text { Meningkatkan } \\
\text { proliferasi limfosit pada } \\
\text { mencit yang diinduksi } \\
\text { cisplatin }\end{array}$ & in vivo & $\begin{array}{l}\text { Meningkatkan ekspresi } \\
\text { IFN- } \gamma\end{array}$ & $\begin{array}{l}\text { Shruthi et } \\
\text { al., } 2018\end{array}$ \\
\hline $\begin{array}{l}\text { Asam } \\
\text { ferulat }\end{array}$ & Antioksidan & in vitro & $\begin{array}{l}\text { Menurunkan ROS dan } \\
\text { menghambat lipid } \\
\text { peroksidase }\end{array}$ & $\begin{array}{l}\text { Kim et al., } \\
\quad 2011\end{array}$ \\
\hline $\begin{array}{l}\text { Asam } \\
\text { klorogena } \\
\mathrm{t}\end{array}$ & Imunostimulan & in vivo & $\begin{array}{l}\text { Meningkatkan produksi } \\
\text { IFN- } \gamma\end{array}$ & $\begin{array}{l}\text { Huang et } \\
\text { al., } 2018\end{array}$ \\
\hline \multirow[t]{2}{*}{ Mirisetin } & $\begin{array}{l}\text { Meningkatkan } \\
\text { proliferasi sel } \\
\text { CD4+CD25+ }\end{array}$ & in vivo & $\begin{array}{l}\text { Menurunkan ekspresi } \\
\text { TGF- } \beta\end{array}$ & $\begin{array}{c}\text { Singh et al., } \\
2017\end{array}$ \\
\hline & Imunostimulan & $\begin{array}{c}\text { in } \\
\text { silico }\end{array}$ & $\begin{array}{l}\text { Menghambat reseptor } \\
\text { TGF- } \beta\end{array}$ & $\begin{array}{c}\text { Singh et al., } \\
2017\end{array}$ \\
\hline \multirow[b]{2}{*}{ Kuersetin } & $\begin{array}{l}\text { Meningkatkan jumlah } \\
\text { IgM }\end{array}$ & in vivo & $\begin{array}{l}\text { menurunkan ekspresi } \\
\text { TGF- } \beta \text { dan IL- } 8\end{array}$ & $\begin{array}{l}\text { Wang et al., } \\
2020\end{array}$ \\
\hline & Sitotoksik & in vitro & $\begin{array}{l}\text { Pada konsentrasi tinggi } \\
\text { menaikkan sitotoksisitas } \\
\text { cisplatin terhadap sel } \\
\text { C13* }\end{array}$ & $\begin{array}{l}\text { Li et al., } \\
2014\end{array}$ \\
\hline
\end{tabular}

Paparan terkait aktivitas sitotoksik dan imunomodulator ekstrak biji duwet (Tabel 1) mengarahkan pada kesimpulan bahwa ekstrak biji duwet memiliki potensi untuk dikembangkan menjadi agen pendamping kemoterapi. Potensi biji duwet sebagai agen pendamping kemoterapi dan prediksi mekanismenya diilustrasikan dalam Gambar 1 . Pemberian kemoterapi mengeradikasi sebagian sel-sel kanker. Penambahan ekstrak biji duwet akan meningkatkan efektivitas terapi melalui efek sitotoksik dan menghambat pensinyalan TGF- $\beta$ pada sel kanker maupun efek imunomodulator dengan memodulasi sitokin-sitokin pada sel-sel sistem imun, sehingga didapatkan kondisi homeostasis. 
Ekstrak biji duwet juga berpotensi untuk dikembangkan dalam bentuk sediaan farmasetika ataupun nutrasetika sehingga meningkatkan nilai akseptibilitas dan nilai jual dari ekstrak biji duwet. Biji duwet dapat pula dikembangkan menjadi komoditas sediaan herbal dengan klaim aktivitasnya sebagai agen immune booster/immunostimulant sehingga pasarnya semakin luas. Pengembangan potensi biji duwet sebagai agen imunoterapi memiliki tantangan, yaitu perlu dilakukan penelitian lanjutan untuk memvalidasi potensi biji duwet tersebut melalui uji in vivo pada hewan uji model kanker yang diberi ekstrak biji duwet dan yang dikombinasikan dengan agen antikanker.
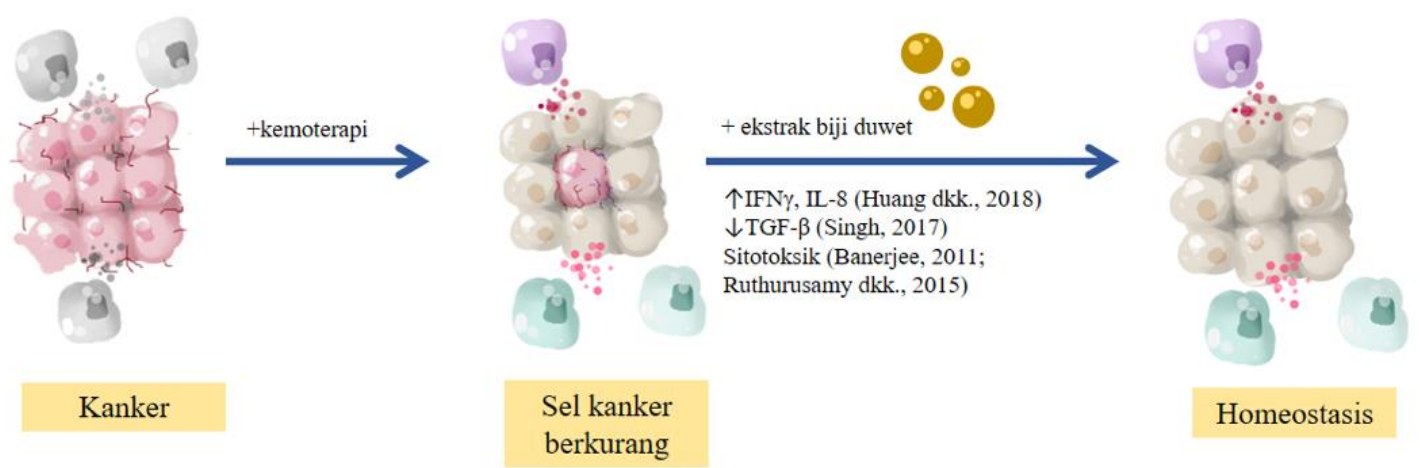

Gambar 1. Potensi aktivitas ekstrak biji duwet sebagai pendamping kemoterapi dan prediksi mekanismenya. Sel berwarna abu-abu merepresentasikan sel sehat, sel merah muda adalah sel kanker, sel hijau dan ungu merepresentasikan sel-sel sistem imun, sedangkan titik-titik abu-abu dan merah adalah sitokin yang dihasilkan sel sehat dan sel-sel sistem imun.

\section{Kesimpulan}

Biji duwet memiliki potensi untuk dikembangkanmenjadi agen pendamping kemoterapi melalui aktivitas imunomodulatornya. Penelitian lebih lanjut pada model hewan uji kanker yang diberi ekstrak biji duwet dan kombinasinya dengan antikanker diperlukan untuk memvalidasi potensi tersebut.

\section{Ucapan Terimakasih}

Ucapan terima kasih disampaikan kepadaDirektorat Jenderal Pembelajaran dan Kemahasiswaan Kementrian Pendidikan dan Kebudayaan Republik Indonesia yang telah mendanai penulisan ulasan ini melalui Program Kreativitas Mahasiswa-Penelitian Eksakta (PKM-PE) tahun 2020.

\section{Deklarasi Konflik Kepentingan}

Semua penulis menyatakan tidak ada konflik kepentingan terhadap naskah ini. 


\section{Daftar Pustaka}

Arun, R., Prakash, M.V.D., Abraham, S.K. dan Premkumar, K. (2011). Role of Syzygium cumini seed extract in the chemoprevention of in vivo genomic damage and oxidative stress. Journal of Ethnopharmacology, 134(2):pp.329-333. 10.1016/j.jep.2010.12.014.

Ayyanar, M. dan Subash-Babu, P. (2012). Syzygium cumini (L.) Skeels: a review of its phitochemical constituents and traditional uses. Asian Pacific Journal of Tropical Biomedicine,2(3): pp.240-246. 10.1016/S2221-1691(12)60050-1.

Bagnyukova, T.V., Serebriiskii, I.G., Zhou, Y., Hopper-Borge, E.A., Golemis, E.A., dan Astsaturov, I. (2010). Chemotherapy and signaling: How can targeted therapies supercharge cytotoxic agents? Cancer Biology and Therapy, 10(9):pp.839-853. 10.4161/cbt.10.9.13738

Balyan, U. dan Sarkar, B. (2017). Aqueous extraction kinetics of phenolic compounds from jamun (Syzygium cumini L.) seeds. InternationalJournal of Food Properties, 20(2): pp.372-389. 10.1080/10942912.2016.1163266.

Banerjee, J. dan Narendhirakannan, R.T. (2011). Phytochemical analyses, antibacterial, in vitro antioxidant and cytotoxic activities of ethanolic extract of Syzygium cumini (L.) seed extract. International Journal of Pharmaceutical Sciences and Research, 2(7): pp.1799-1806. 10.13040/IJPSR.0975-8232.2(7).1799-06.

Chen, L. dan Yu, J. (2016). Modulation of Toll-like receptor signaling in innate immunity by natural products. International Immunopharmacology, 37: pp.65-70. 10.1016/j.intimp.2016.02.005.

Galluzzi, L., Buqué, A., Kepp, O., Zitvogel, L. dan Kroemer, G. (2015). Immunological effects of conventional chemotherapy and targeted anticancer agents. Cancer Cell, 28(6): pp.690-714. 10.1016/j.ccell.2015.10.012.

Gibbs, L., Bowen, R., Makris, A., UKBCM, dan Beresford, M. (2016). Preferences for chemotherapy side-effect profiles in breast cancer - the view of oncologists. Clinical Oncology, 28(5): E3-E4. 10.1016/j.clon.2016.01.022.

Gowri, S.S. dan Vasantha, K. (2010). Phytochemical screening and antibacterial activity of Syzygium cumini (L.) (Myrtaceae) leaves extracts. International Journal of PharmTech Research, 2(2): pp.1569-1573.

Huang, H., Pan, L., Pan, S. dan Song, M. (2018). The feasibility of using primary shrimp hemocyte culture to screen herbal immunostimulants. Aquaculture International, 26: pp.799-811. 10.1007/s10499-018-0238-2.

Hui-Chou, H.G., Olenczak, J.B., Drachenberg, C.B., Shea, S.M. dan Rodriguez, E.D. (2012). Short-term application of doxorubicin chemotherapy immunosuppressive side effects for composite tissue allotransplantation. Annals of Plastic Surgery, 68(2): pp.215-221. 10.1097/SAP.0b013e3182467f7b.

Imanuel, L.K., Sunarni, T., dan Herdwiani, W. (2021). Aktivitas sitotoksik dan ekspresi protein p53 dan bcl-2 ekstrak dan fraksi daun yakon (Smallanthus sonchifolius) terhadap sel kaknker T47D. Journal of Pharmaceutical Science and Clinical Research, 6(1): pp.74-81. 10.20961/jpscr.v6i1.39540.

Kementerian Kesehatan RI. (2019). Penyakit kanker di Indonesia berada pada urutan 8 di Asia Tenggara dan 23 di Asia. http://p2p.kemkes.go.id/penyakit-kanker-di-indonesiaberada-pada-urutan-8-di-asia-tenggara-dan-urutan-23-di-asia/ [20 September 2020].

Kesuma, D., Siswandono, Purwanto, B.T., dan Hardjono, S. (2018). Uji in silico aktivitas sitotoksik dan toksisitas senyawa turunan $\mathrm{N}$-(benzoil)-N'-feniltiourea sebagai calon obat antikanker. Journal of Pharmaceutical Science and Clinical Research, 3(1): pp.11-11. 10.20961/jpscr.v3i1.16266.

Kim, H.-Y., Park, J., Lee, K.-H., Lee, D.-U., Kwak, J.-H., Kim, Y.S. dan Lee, S.-M. (2011). Ferulic acid protects against carbon tetrachloride-induced liver injury in mice. Toxicology, 282(3): pp.104-111. 10.1016/j.tox.2011.01.017. 
Lee, S.N., Jin, S.M., Shin, H.S. dan Lim, Y.T. (2020). Chemical strategies to enhance the therapeutic efficacy of Toll-like receptor agonist based cancer immunotherapy. Accounts of Chemical Research, 53(10): pp.2081-2093. 10.1021/acs.accounts.0c00337.

Li, N., Sun, C., Zhou, B., Xing, H., Ma, D., Chen, G. dan Weng, D. (2014). Low concentration of quercetin antagonizes the cytotoxic effects of anti-neoplastic drugs in ovarian cancer. PLoS ONE, 9(7): e100314. 10.1371/journal.pone.0100314.

Liu, M. dan Guo, F. (2018). Recent updates on cancer immunotherapy. Precision Clinical Medicine, 1(2): pp.65-74. 10.1093/pcmedi/pby011.

Mastan, S.K., Saraseeruha, A., Gourishankar, V., Chaitanya, G., Raghunandan, N., Reddy, G.A. dan Kumar, K.E. (2008). Immunomodulatory activity of methanolic extract of Syzygium cumini seeds. Pharmacologyonline. 3: pp.895-903.

Pai, R.J., Valder, B., Palatty, P.L., Shivashankara, A.R. dan Baliga, M.S. (2013). Gastrointestinal protective effects of Eugenia jambolana Lam. (blackplum) and its phytochemicals, 369-382, in: Watson, R.R. and Preedy, V.R. (Eds.), Bioactive Food as Dietary Interventions for Liver and Gastrointestinal Disease. San Diego: Academic Press. 10.1016/B978-0-12-397154-8.00043-9.

Plants of the World Online (POWO). (2019). Syzygium cumini (L.) Skeels. http://www.plantsoftheworldonline.org/taxon/urn:lsid:ipni.org:names:601603-1 [20 September 2020].

Ramya, S., Neethirajan, K. dan Jayakumararaj, R. (2012). Profile of bioactive compounds in Syzygium cumini - a review. Journal of Pharmacy Research, 5(8): pp.4548-4553.

Rodrigues, K.A. da F., Amorim, L.V., Dias, C.N., Moraes, D.F.C., Carneiro, S.M.P., Carvalho, F.A. de A. (2015). Syzygium cumini (L.) Skeels essential oil and its major constituent $\alpha$-pinene exhibit anti-Leishmania activity through immunomodulation in vitro. Journal of Ethnopharmacology, 160: pp.32-40. 10.1016/j.jep.2014.11.024.

Ruthurusamy, S.K., Dheeba, B., Hameed, S.S., dan Palanisamy, S. (2015). Anti-cancer and anti-oxidative potential of Syzygium cumini against breast cancer cell lines. Journal of Chemical and Pharmaceutical Research, 7(10): pp. 449-460.

Shruthi, S., Vijayalaxmi, K.K. dan Shenoy, K.B. (2018). Immunomodulatory effects of gallic acid against cyclophosphamide- and cisplatin-induced immunosuppression in Swiss Albino mice. Indian Journal of Pharmaceutical Sciences, 80(1): pp.150-160. 10.4172/pharmaceutical-sciences. 1000340.

Singh, P., Bast, F. dan Singh, R.S. (2017). Natural compounds targeting transforming growth factor- $\beta$ : in silico and in vitro study. Electronic Journal of Biology, 13(1): pp.6-13.

Syama, H.P., Arya, A.D., Dhanya, R., Nisha, P., Sundaresan, A., Jacob, E. dan Jayamurthy, P. (2017). Quantification of phenolics in Syzygium cumini seed and their modulatory role on tertiary butyl-hydrogen peroxide-induced oxidative stress in H9c2 cell lines and key enzymes in cardioprotection. Journal of Food Science and Technology, 54: pp.21152125. 10.1007/s13197-017-2651-3.

Travis, M.A. dan Sheppard, D. (2014). TGF- $\beta$ activation and function in immunity. Annual Review of Immunology, 32: pp.51-82. 10.1146/annurev-immunol-032713-120257.

United States Departement of Agriculture. (2015). Natural Resources Conservation Service: Plant Profile Classification Syzygium cumini. https://plants.usda.gov/core/profile?symbol=SYCU [20 September 2020].

Wagner, M. dan Koyasu, S. (2019). Cancer immunoediting by innate lymphoid cells. Trends in Immunology,40(5): pp. 415-430. 10.1016/j.it.2019.03.004.

World Health Organization (WHO). (2018). Cancer. https://www.who.int/news-room/factsheets/detail/cancer\#: :text=Cancer\%20is\%20the\%20second\%20leading, $\% 20$ and $\% 20 \mathrm{~m}$ iddle-income\%20countries [20 September 2020].

Wang, J., Zhang, C., Zhang, J., Xie, J., Yang, L., Xing, Y. dan Li, Z. (2020). The effects of quercetin on immunity, antioxidant indices, and disease resistance in zebrafish (Danio 
rerio). Fish Physiology and Biochemistry, 46: pp.759-770. 10.1007/s10695-019-007502.

Yadav, D.K., Khan, F. dan Negi, A.S. (2012). Pharmacophore modeling, molecular docking, QSAR, and in silico ADMET studies of gallic acid derivatives for immunomodulatory activity. Journal of Molecular Modeling, 18: pp.2513-2525. 10.1007/s00894-011-12653.

Yang, K., Zhang, L., Liao, P., Xiao, Z., Zhang, F., Sindaye, D., Xin, Z., Tan, C., Deng, J., Yin, Y. dan Deng, B. (2020). Impact of gallic acid on gut health: focus on the gut microbiome, immune response, and mechanisms of action. Frontiers in Immunology, 11: 580208. 10.3389/fimmu.2020.580208.

Zhang, X.-Y., Li, W.-G., Wu, Y.-J. dan Gao, M.-T. (2005). Amelioration of doxorubicininduced myocardial oxidative stress and immunosuppression by grape seed proanthocyanidins in tumour-bearing mice. Journal of Pharmacy and Pharmacology, 57(8): pp.1043-1051. 10.1211/0022357056523.

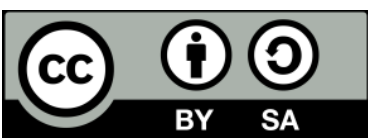

(C) 2021 by the authors. Submitted for possible open access publication under the terms and conditions of the Creative Commons Attribution-ShareAlike 4.0 International (CC BY-SA 4.0) license (https://creativecommons.org/licenses/by-sa/4.0/). 